\title{
DUST CONTROL ON ANDESITE STONE PROCESSING INDUSTRY
}

\author{
J. Purwanta* \\ Environmental Engineering Department, UPN “Veteran”, Yogyakarta, Indonesia \\ Suharwanto \\ Environmental Engineering Department, UPN “Veteran”, Yogyakarta, Indonesia \\ T. Ristyowati \\ Industrial Engineering Department, UPN “Veteran”, Yogyakarta, Indonesia \\ *Corresponding Author: jakapurwanta_tlupn@yahoo.co.id
}

\begin{abstract}
The research aims to make efforts to control dust generated in the processing industry of stones. This industrial location in the village Hargomulyo, Kokap, Kulon Progo, Yogyakarta. This study background that the andesite stroke processing industry, especially in the stone crusher tool with the flow of exhaust gas, dust arise in large numbers. Their media scattered wind the wind-borne dust is so dispersed into the environment around the site and it is dangerous to public health. It is necessary to control the spread of dust. The research was conducted in the laboratory and simulation using dust extraction equipment fogging method. Optimized variable is the diameter of the nozzle, while the others held constant magnitude replications, then the results are averaged. After doing research, the research data obtained that the optimum conditions mass of dust captured by the mist that is the nozzle diameter of $1.50 \mathrm{~mm}$ with an average mass of dust that can be captured by the mist that is $13327.33 \mathrm{~g}$ and an average efficiency value $70.69 \%$. Equation of a line that states the relationship between the variable diameter of the nozzle by the symbol X Masses of dust captured by the mist by the symbol Yie $Y=392 . X 3+3969,9 X 2+10090 X$ +5542.4 the percent error $0.77 \%$, while the equation stating the relationship between variables within the sprayer to the tools by the symbol $X$ with the value of efficiency by the symbol Yie $Y=1,2333 X 3-13,528 X 2+40,199 X+33.878$ with percent average error of $0.54 \%$. An increase in the efficiency of dust extraction tool is then expected spread of dust into the environment as a result of the processing of andesite can be minimized so that the air quality around the site will be maintained well.
\end{abstract}

Keywords: Processing, distribution, control, misting, efficiency.

Cite this Article: J. Purwanta, Suharwanto and T. Ristyowati, Dust Control on Andesite Stone Processing Industry. International Journal of Civil Engineering and Technology, 11(2), 2020, 114-119.

https://iaeme.com/Home/issue/IJCIET?Volume=11\&Issue $=2$ 


\section{INTRODUCTION}

Andesite stone processing industry, especially in the stone crusher tool, will give rise to dust. The wind is blowing the dust will spread to the entire environment around the site. According Suhariyono and Wiyono [5],some of the main sources of dust in the atmosphere is a blast of sea water, soil, household combustion, bushfires, motor vehicles, organic dust from plant materials, and industrial processes. Dust from industrial processing of solid materials in the dust that is of concern. Dust that has a greater ability to penetrate into the lungs is dust smaller than $10 \mathrm{~lm}$. Dust larger than $10 \mu \mathrm{m}$ are filtered out by the nose hairs, while particles smaller than the size of the bubbles can get into the lungs and exhibit Brownian motion and do not hit the wall. Particles smaller than $2.5 \mu \mathrm{m}$ (PM2,5) will stick to the lungs due to bubbles can not be filtered out in the upper respiratory system and this condition will be able to lower gas exchange,PM10 particulate materials include particles of aerodynamic diameter less than 10 $\mathrm{lm}$. The dust particles will result in increasingly poor health can reach the lower respiratory tract or the so-called X-ray. It goes it will be attacked by ARI (Acute Respiratory Infection). Reduced public income due to an ARD public can not work so it does not have an income from their tertiary impact of the dust, The decrease in the level of the community's economy is the continuing impact of the decline in public revenue, According Dimitriou and Christidou [1],environmental problems which resulted in a high temperature effects that affect public health, natural ecosystems, animal life, and the man-made environment, caused by air pollution. Air pollution also led to the greenhouse effect, acid rain, climate change, etc.,

Another opinion explains that the dust caused lung disease chronic obstructive, impaired lung function, restrictive lung disease, lung carcinoma, pneumoconiosis, stomach, and colon. (Ather Sultan [6]). Impaired lung function caused by exposure via inhalation of dust particles in the respiratory tract. In accordance with the nature of chemistry, physics, and biology of these dust particles then the dust will accumulate in the respiratory tract. (Nurbiyantara [3]). Dust termed TSP defined as PM (Particulate Material) with aerodynamic diameter not more than $30 \mathrm{~lm}$. (Naqpure [2]).According Otaru et al [4], Hardware controllers dust which is used in the plant that is the Electrostatic Precipitator (ESP) and Bag Filters (BF) and the process used in this study, as the media dust catcher on the appliance dust extraction method of fogging is fog, (Otaru et al [4])

\section{MATERIALS \& EXPERIMENTAL PROCEDURES}

\subsection{Research Sites}

Location of research in the mining area of andesite and andesite stone processing industry PT. Indokarya Mitra Sejahtera in Hargomulyo, Kokap, Kulon Progo, Yogyakarta.

\subsection{Materials and Equipment}

This study using materials and equipment such as dust, water, nozzles, tubes, generating tools fog, and dust gauges.

\subsection{Method}

\subsubsection{Perform optimization of operating conditions of equipment on the variable diameter nozzle sprayer on the dust catcher equipment fogging method}

In this study, the value of temperature, humidity, and air quality changes is an influential factor in the formation of fog. Dust extraction equipment misting method can be seen in Figure 1 . 


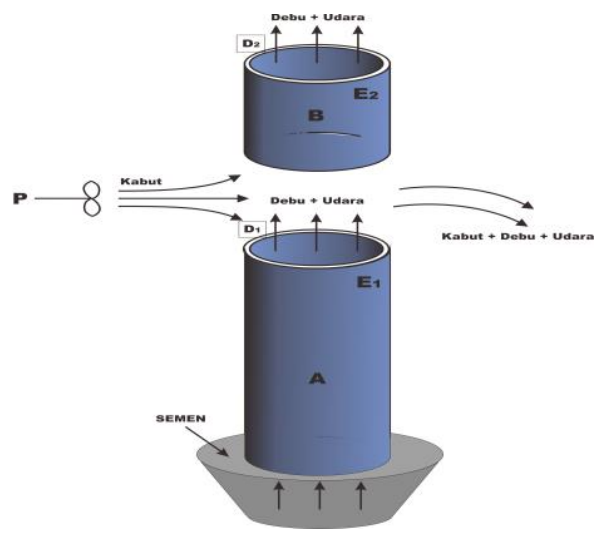

Information:

A: Pipes AE: exhauster

B: Pipe BP: Tolkit

D: Dust Collector

Figure 1. The circuit schematic tool on the fogging method

(Source: the author, 2020)

\subsubsection{Dust catcher Laboratory Scale Test}

Material and dust extraction tool fogging method will be tested by a laboratory scale. As the independent variable is the diameter of the nozzle (Dn) whereas as fixed variables, namely the distance between the sprayer to the tool $(\mathrm{L}=2 \mathrm{~m})$, airspeed in column $(\mathrm{Vu}=430 \mathrm{~m}$ per $\mathrm{min})$, the distances between the top end of the chimney with the gauge $(Z=100 \mathrm{~cm})$, and the velocity of the water going into the sprayer $(\mathrm{Va}=110 \mathrm{ml} / \mathrm{min})$.

\subsubsection{Data Analysis}

The granules are very small mist managed to capture very fine dust. Cement dust capture rate can be determined by ANOVA analysis with an error rate of less than 5\% percent.

The percentage reduction in dust emissions can be calculated as the level of efficiency that is as follows:

$$
\% \text { Reduction (efficiency) }=100 \%-100 \times \text { avg. dust caught fog }
$$

$$
\text { avg. before fogging }
$$

Efficiency indicates the level of performance of these tools are calculated based on the amount of dust captured by the mist.

\section{RESULTS AND DISCUSSION}

Work efficiency of the dust catcher tool misting method can be calculated and shown in Tables 1 and 2. 
Table 1. Dust Caught by fog on the Tools Dust Catcher fogging method with Variable Nozzle Diameter (Dn)

\begin{tabular}{ccccc}
\hline No. & $\begin{array}{c}\text { Nozzle diameter } \\
(\mathbf{m m})\end{array}$ & $\begin{array}{c}\text { The } \\
\text { measurement } \\
\text { sequence to }\end{array}$ & before misting & Dust mass (g) \\
before misting
\end{tabular}

Source: Sports Data, 2020

Table 2. The dust mass average Caught by fog and working efficiency Dust Catcher Equipment fogging method average with Variable Nozzle Diameter (Dn)

\begin{tabular}{|c|c|c|c|c|c|c|}
\hline No. & $\begin{array}{c}\text { Nozzle } \\
\text { diameter } \\
(\mathbf{m m})\end{array}$ & $\begin{array}{c}\text { The } \\
\text { measurement } \\
\text { sequence to }\end{array}$ & $\begin{array}{l}\text { The dust mass } \\
\text { is caught fog } \\
\text { (g) }\end{array}$ & $\begin{array}{l}\text { The average } \\
\text { mass of dust } \\
\text { caught in the } \\
\text { fog (g) }\end{array}$ & $\begin{array}{c}\text { Efficiency } \\
(\%)\end{array}$ & $\begin{array}{c}\begin{array}{c}\text { Average } \\
\text { efficiency }\end{array} \\
(\%)\end{array}$ \\
\hline \multirow[t]{3}{*}{1} & 1.80 & 1 & 11990 & 11490.00 & 58.69 & \\
\hline & & 2 & 11995 & & 58.15 & 58.27 \\
\hline & & 3 & 11980 & & 57.96 & \\
\hline \multirow[t]{3}{*}{2} & 1.50 & 1 & 13237 & 11988.33 & 61.65 & \\
\hline & & 2 & 13385 & & 61.91 & 61.77 \\
\hline & & 3 & 13360 & & 61.75 & \\
\hline \multirow[t]{3}{*}{3} & 1.20 & 1 & 10280 & 13327.33 & 70.56 & \\
\hline & & 2 & 10160 & & 70.76 & 70.69 \\
\hline & & 3 & 10060 & & 70.76 & \\
\hline \multirow[t]{3}{*}{4} & 0.90 & 1 & 7730 & 10166.67 & 65.23 & \\
\hline & & 2 & 7610 & & 64.71 & 64.85 \\
\hline & & 3 & 7850 & & 64.61 & \\
\hline \multirow[t]{3}{*}{5} & 0.60 & 1 & 5680 & 7730.00 & 57.69 & \\
\hline & & 2 & 5775 & & 56.96 & 57.32 \\
\hline & & 3 & 5485 & & 57.30 & \\
\hline
\end{tabular}

Source: Sports Data, 2020

Based on experimental data with a variable nozzle diameter will be graphed to see the relationship between the size of the nozzle diameter with a mass of dust that can be captured by the mist and the efficiency of dust extraction tool such fogging method. 
Dust Control on Andesite Stone Processing Industry

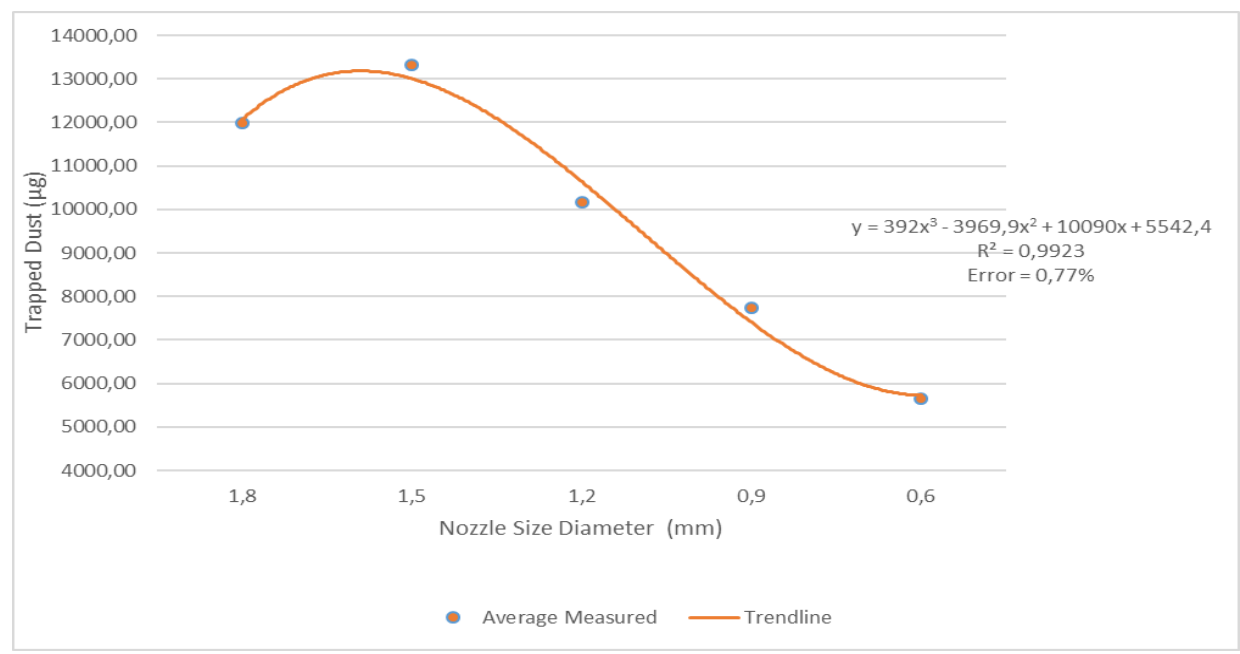

Figure 2. The relationship between the size of the nozzle diameter with a mass of dust caught in the fog

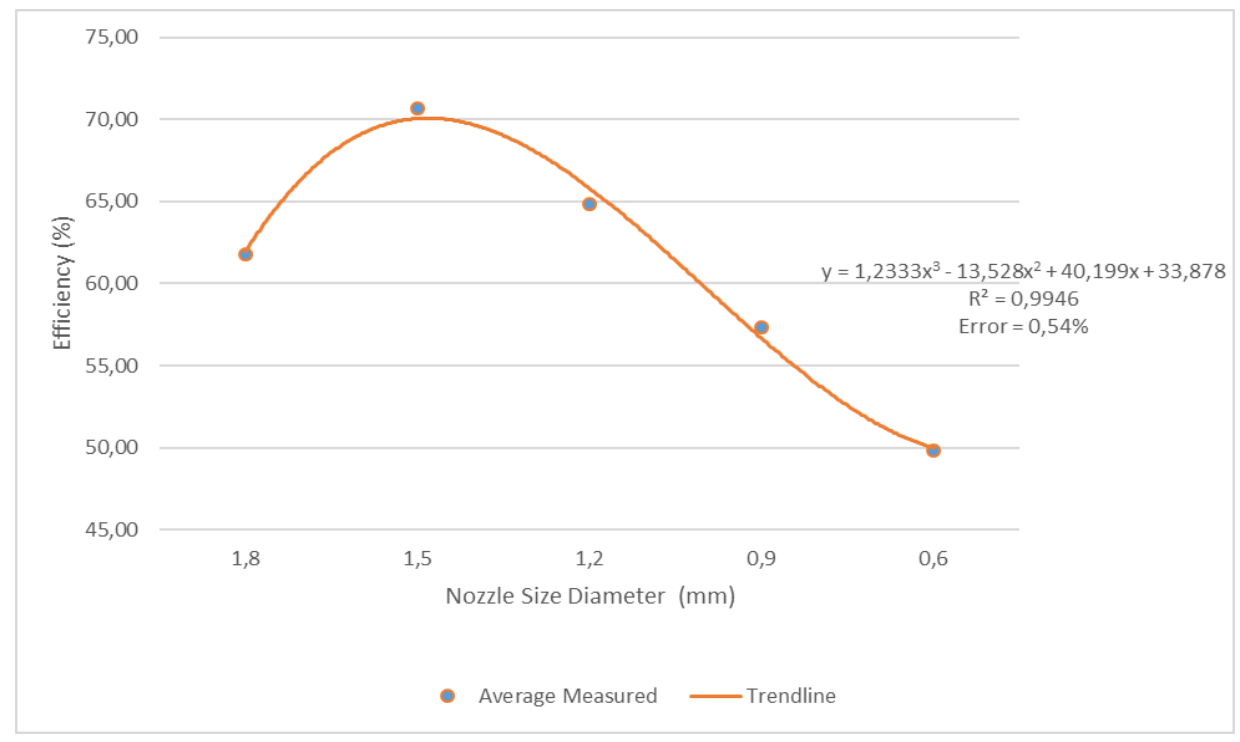

Figure 3. The relationship between the size of the diameter of the nozzle with the efficiency of the appliance. penangkap dust fogging method

Based on the graph above it can be seen that the larger the diameter of the nozzle, the more the mass of dust that can be captured by the mist generated in the dust catcher tool fogging method. Optimal conditions occur in the nozzle diameter of $1.50 \mathrm{~mm}$ with the average mass of dust that can be captured by the mist that is $13327.33 \mathrm{~g}$ but the larger nozzle diameter is $1.80 \mathrm{~mm}$, it is the mass of the dust is caught will be less. This condition will affect the efficiency of the dust extraction tool fogging method. The larger the diameter of the nozzle used in the sprayer, the higher the efficiency of dust extraction tool fogging method. Optimal conditions occur in the nozzle diameter of $1.50 \mathrm{~mm}$ with the efficiency of $70.69 \%$, but on a larger nozzle diameter is $1.80 \mathrm{~mm}$, it is the efficiency of the tool will be decreased. 
While analysis of the quality of the fog dispraykan associated with a variable nozzle diameter is as follows:

1) $1,80 \mathrm{~mm} \quad$ : fog sprayer largely shaped so that the water mist is formed is not perfect.

2) $1.50 \mathrm{~mm}:$ Sprayer mist formed, the exact position of the air flow which carries dust so that it can optimally capture dust.

3) $1.20 \mathrm{~mm} \quad$ : Sprayer haze that is less than perfect it can not bind the dust perfectly so heavy that there is little difference.

4) $0.90 \mathrm{~mm} \quad$ : Spayer haze that is less than perfect it can not bind the dust perfectly so heavy that there is little difference.

5) $0,60 \mathrm{~mm}:$ : The fog that has not materialized sprayer caught fog then very little dust.

Based on the analysis above, the optimal conditions for variable nozzle diameter of 1.50 $\mathrm{mm}$ occurs on the average mass of dust that can be captured by the mist that is $13327.33 \mathrm{~g}$ and the efficiency of $70.69 \%$.

\section{SUMMARY}

The optimum operating conditions in cement dust extraction tool meteode fogging occurs on the size of the nozzle diameter of $1.50 \mathrm{~mm}$ with an average mass of dust that can be captured by the mist that is 13327.33 gand the value of the average efficiency of $70.69 \%$. In such operating conditions, dust catcher tool misting method can capture fine dust optimally. This can reduce the spread of dust into the environment so as to improve air quality.

\section{ACKNOWLEDGMENTS}

Fogging method used in dust extraction tool is the latest innovation tool that can be developed environmentally-friendly well from the operation and equipment variables to obtain products of better efficiency.

\section{REFERENCES}

[1] Dimitriou, A. and Christidou, V., 2011, Causes and Consequences of Mix Pollution and Environmental Injustice As Critical Issues For Sciences and Environmental Education, p.218, The Impact of Air Pollution on Health, Economy, Environment, and Agricultural Sources, In Tech.

[2] Naqpure, A.S., et al, 2014, "Human Health Risks In National Caiptal Territory Of Delhi due to Air Pollution”, p.373, Atmospheric Pollution Research, India.

[3] Nurbiyantoro, S., 2010, "Pengaruh Polusi Udara Terhadap Fungsi Paru-Paru Polisi Lalu Lintas Di Surakarta”, hal.44-45, UNS, Surakarta Dampak Sosial-Ekonomi Pabrik Semen Puger Di Kecamatan Puger Kabupaten Jember, Jember.

[4] Otaru, A.J., Odigure, J.O., Okafor, J.O., and Abdulkareem, A.S., 2013, Investigation into particulate pollutant concentration from a cement plant: a case study of Obajana Cement Plc, Lokoja, Nigeria, IQSR Journal of Environmental Science, Toxicology, and Food Technology (IQSR-JESTFT), Volume 3, Issue 2, pp.89-96, Nigeria.

[5] Suhariyono, G. dan Wiyono, M., 2003, "Distribusi Diameter Partikel Debu PM10 dan $P M_{2,5}$ dalam Udara Sekitar Kawasan Pabrik semen Citeureup, Bogor”, Prosiding Seminar Aspek Keselamatan Radiasi dan Lingkungan Pada Industri Non Nuklir 18 maret 2003, Jakarta.

[6] Sultan, A., 2004, "Health Hazards of Cement Dust”, Saudia Medical Journal 25 (9):11539. 